\title{
İleri Evre Demans Hastasında Hemşirelik Bakımı: Olgu Sunumu
}

\author{
Nursing Care of Advanced Stage Dementia Patient: Case Report
}

\author{
Filiz DİLEK ${ }^{\mathrm{a}}$, Aysun ÜNAL ${ }^{\mathrm{b}}$, Serap ÜNSAR ${ }^{\mathrm{c}}$
}

\begin{abstract}
ÖZET Alzheimer, yaşılılarda en sık görülen demans tipidir. Nöral yapılarda ilerleyici hücre kaybıyla karakterize, ilerleyici bir hafiza kaybı tablosudur. 65 yaş ve üzeri yaşa sahip her 9 kişiden birini etkilemektedir. Uzun süreli bakım gerektiren Alzheimer hastalığında hasta ve ailesi bir bütün olarak ele alınmalıdır. Bu olgu sunumda; Gordon'un fonksiyonel sağlı örüntüleri modeli doğrultusunda ileri evre bir Alzheimer hastası değerlendirilerek hemşirelik bakım planı oluşturulması amaçlanmıştır.
\end{abstract}

Anahtar kelimeler: Alzheimer hastalığı; hemşirelik bakımı; Gordon'un fonksiyonel sağlık örüntüleri modeli.

\begin{abstract}
Alzheimer is the most common type of dementia in elderly. Alzheimer's disease is characterized by progressive loss of neural cell structure and progressive loss of memory. The disease effects one in nine of the people with age 65, and older. Alzheimer's disease requires long-term care of patients and their families should be addressed as a whole. In this case report; a patient with diagnosis of advanced stage of Alzheimer's disease is reported and the aim is to make a scheduled nursing care plan according to Gordon's functional health patterns.
\end{abstract}

Key words: Alzheimer's disease; nursing care; Gordon’s functional health patterns

\section{Giriş}

Demans bilişsel ve entellektüel işlevlerde azalma sonucu; bellek, konuşma, algılama, hesaplama, yargilama, soyut düşünme ve problem çözme gibi işlevlerde bozulmaya sebep olan merkezi sinir sisteminin ilerleyici dejeneratif bir hastalığıdır, ${ }^{1,2}$ Yaşl11ıkta $\mathrm{sik}$ görülen damarsal ve dejenaratif değişimlere bağlı gelişen demans hastalıklarının başında \%50-70 arasında değișen oranlarıyla Alzheimer hastalığı (AH) gelmektedir ${ }^{3}$. En önemli risk faktörü yaştır. AH, 65 yaş ve üzeri yaşa sahip her dokuz kişiden birini etkilemektedir ${ }^{4}$. Prevalans1 60 yaşından sonra her beş senede bir, iki katına çıkmaktadır. Araştırmalarda kadınlarda Alzheimer riski erkeklerden daha fazla bulunmuştur ${ }^{5,6}$. 2016 y1lında Amerika birleşik devletlerinde Alzheimer hastalığına sahip kişilerin \%44'ü 75-84 yaş aralığındadır ve
Alzheimer tüm yaşlara sahip Amerikalıların 5.4 milyonunu etkilemektedir ${ }^{4}$. Türkiye'de 2014 yılında Teşhis İlişkili Gruplar (TIG) veri tabanından elde edilen verilere göre 18.158 hastaya Alzheimer tanısı konmuştur. Yaş gruplarına göre dağılımı incelendiğinde en çok görülen yaş grubunun 70-84 yaş olduğu, kadınlarda erkeklerden daha fazla görüldüğü saptanmıştır. Batı illerinde ve büyük şehirlerde daha fazla görülmektedir. ${ }^{7}$ Toplumun yaşlanması ve ülkemizdeki yaşlı nüfus oranının artmasına bağlı olarak AH'lı yaşlı sayısının artması beklenmektedir. $^{2}$

Yaş, düşük sosyo-ekonomik düzey, aile öyküsü, kadın cinsiyet, down sendromu, Apo E 4 alleli, depresyon, yüksek kan basıncı, kolesterol yüksekliği, homosistein yüksekliği, tip 1 diyabet $\mathrm{AH}$ için risk faktörleri olarak sayılmaktadır. ${ }^{2,5} \mathrm{AH}$ ' nın oluşma riskini azalttığ 1

\footnotetext{
Geliş Tarihi/Received: 26-12-2016 / Kabul Tarihi/Accepted:10-05-2017

a Öğretim Görevlisi, Namık Kemal Üniversitesi Sağlık Hizmetleri Meslek Yüksekokulu, e-posta: fdilek@nku.edu.tr, İş Telefonu:0 2822503308

b Profesör, Namık Kemal Üniversitesi Tıp Fakültesi Nöroloji Anabilim Dalı,e-posta: aunal@nku.edu.tr

c Profesör, Trakya Üniversitesi Sağlık Bilimleri Fakültesi, Hemşirelik Bölümü, İç Hastalıkları Hemşireliği Anabilim Dalı, eposta: serapunsar@trakya.edu.tr

Sorumlu yazar /Correspondence: Öğr. Görv. Filiz Dilek, Namık Kemal Üniversitesi Sağlık Hizmetleri Meslek

Yüksekokulu, e-posta: fdilek@nku.edu.tr, İş Telefonu:02822503308
} 
düşünülen koruyucu faktörler ise $\mathrm{ApoE}$ e2 alleline sahip olma, non-steroid antiinflamatuvar ilaçların kullanımı ve yüksek eğitimdir ${ }^{5}$. AH, unutkanlıkla başlayarak; tam bağımlılığa ilerleyen erken, orta ve ileri evre olmak üzere üç evreye ayrılmaktadır. ${ }^{2,8}$ Tanı, hasta öyküsü, fizik ve nörolojik muayene, nöropsikolojik testler, görüntüleme yöntemleri ve laboratuvar incelemeleri ile konulmaktadır. Kognitif bozukluğun şiddetini ve/veya demansın evresini değerlendirmede; Kisa Mental Durum Testi (KMDT), Klinik Demans Derecelendirme Ölçeği (CDR) ve Global Bozulma Ölçeği (GDS) kullanılmaktadır ${ }^{9}$. Tedavide birincil amaç, hastalığın kognitif ve bellek bozukluğu semptomlarına odaklanmaktadır. İkincil amaç ise, hastalığın seyri sırasında ortaya çıkan depresyon, halüsinasyon, uyku bozuklukları gibi bulguların azaltılmasını amaçlamaktadır. Bakım yaşam kalitesini arttırıcı ve bakımını destekleyici özelliktedir ${ }^{10}$. Hastalı̆̆ın evresi belirlendikten sonra aile de ele alınarak bireysel problemlere yönelik bütüncül hemşirelik bakımı planlanmalidir.

$\mathrm{Bu}$ çalışmada sunulan olguda $\mathrm{AH}$ hastalığının evresini belirlemek için; hasta öyküsü, KMDT, CDR testlerinden yararlanılmıştır. Olgu, 1982'de Gordon tarafindan geliştirilmiş olan bireylerin biyopsikososyal boyutta kapsamlı olarak ele alındığ 1 hemşirelik bakım modeli ile değerlendirilerek hemşirelik bakım planı oluşturulmuştur. Hasta yakının bakıcı yükünün değerlendirilmesinde; bakım verme yükü ölçeği kullanılmıştır. Olgu ve hasta yakını çalışma hakkında bilgilendirilmiş ve izinleri alınmıştır.

\section{Olgu sunumu}

İleri evre Alzheimer hastası 75 yaşındaki İ.H.T olgu olarak sunulmuştur. Hasta yakınından alınan bilgilere göre, hasta ilkokul mezunu ve emeklidir. İki yıl önce unutkanlık şikayeti ile sağlık kuruluşuna başvuran ve AH tanısı alan hastanın üç ay önce eşi vefat etmiştir. Ağır derecede unutkanlık vardır. Zaman ve mekâna oryante değildir. Ev dışında bağımsızlığını yitirmiştir. Tehlikede olduğuna inanmakta, aile üyelerinin kendisini terk etmeyi düşündüklerini söylemektedir. Ölen anne- babasının kendisini ziyarete geldiğini görmekte ve onlarla konuşmaktadır. Banyo yapma ve giysilerinin değiştirilmesi gibi günlük aktivitelere direnmektedir. Ailesine yük olduğunu ve ölme isteğini belirtmektedir. Paraya düşkünlüğü artmıştır. Evde amaçsızca dolaşmakta, çekmece ve dolapları karıştırmaktadır. Geceleri uykuya dalmakta güçlük yaşamaktadır. Yemek yediğini unutup tekrar yemek istemektedir. KMDT puanı 11'dir, Öykü ve muayene bulguları 1şı̆̆ında Klinik Demans Evreleme ölçeğine göre Evre 3 Alzheimer hastasıdır. Hasta; Memantin $20 \mathrm{mg}$ 1x1, Rivastigmin 15 transdermal flaster $(27 \mathrm{mg}$ rivastigmin) 1x1, Sertralin $50 \mathrm{mg} 1 \mathrm{x} 1$ kullanmaktadır.

Hasta yakını; hastayı aksi, geçinilmesi zor biri olarak tanımlanmaktadır. Hastanın ihtiyacı olduğundan daha fazla yardım istediğini, kendisinin babasının davranışlarından rahatsızlık duyduğunu, kendi sağlığının da bozulduğunu, özel ve sosyal hayatını istediği gibi yaşayamadığını, zaman zaman daha fazla babasının bakımını üstlenemeyeceğini düşündügünü belirtmiştir. Uygulanan bakım verme yükü ölçeğinden 85 puan almıştır.

\section{İHT ‘ un Gordon un fonksiyonel sağlık} örüntüleri modeline göre değerlendirilmesi

1. Sağlığın algılanması: Özgeçmişinde ameliyat öyküsü ve kronik hastalık öyküsü olmayan IHTT 2 yıl önce Alzheimer tanısı almıştır. 3 ayda bir düzenli kontrolleri devam etmektedir.

2. Beslenme şekli ve metabolik durum: hasta yakını İHT nin yemek yemeyi unutup tekrar tekrar yemek istediğini ve elle yemek yediğini belirtmektedir. Kendi yemeğini kendi hazırlayamamaktadır. Yemek yedikten sonra da hasta temizlenmekte yardıma ihtiyaç duymaktadır.

3. Boşaltım şekli: Defekasyonun günde bir kez olduğu, tuvaletin hatırlatılması gerektiği ve hastanın kendini temizlemekte zorluk çektiği belirtilmektedir.

4. Aktivite-egzersiz şekli: Tırnak bakımı, banyo yapma v.b. konularda yardıma gereksinimi vardır. Giysileri seçildiği taktirde giyinip - soyunabilmekte ve banyo yapma, giysilerinin değiştirilmesi gibi günlük aktivitelere hasta direnmektedir. Ev içinde dolaşabilmektedir. Ev dişında bağımsızlığını yitirmiştir.

5. Uyku-istirahat şekli: Geceleri uykuya dalmakta güçlük yaşamaktadır. Tehlikede olduğu ve aile üyelerinin kendisini terk edeceği korkusuyla, geceleri evde kimlerin olduğunu kontrol etmek için dolaşmaktadır. Ortalama günde 4-5 saat uyumaktadır.

6. Bilişsel algılama şekli: İHT de işitme, görme kayb1 yoktur. Zamana ve mekana oryante değildir. Ölen anne ve babasının 
geldiğini görmekte ve onlarla konuşmaktadır. Bir neden olmaksızın göğüs bölgesinin üzerinde bir ağrı olduğunu tanımlamaktadır.

7. Kendini algılama ve Kavrama şekli: Hasta yakını İHT'nin ailesine yük olduğunu, gelecekten umutsuz olduğunu ve ölmek istediğini söylediğini, para ile mutlu olduğunu belirtmektedir. Ev ve arabanın satılarak parasının kendisine verilmesini istemektedir.

8. Rol -ilişki şekli: İHT tehlikede olduğunu, aile üyelerinin kendisini terk etmeye çalıştığını belirtmektedir. Hasta yakını İHT'yi geçinilmesi zor birisi olarak tanımlamakta, davranışlarından rahatsızlık duyduğunu, sosyal ilişkilerinin bozulduğunu ve sosyal-özel hayatını istediği gibi yaşayamadığını belirtmektedir.

9. Cinsellik ve üreme: İHT'nin eși vefat etmiştir. Hasta yakını, İHT’nin hastalığından dolayı kendi özel ve sosyal hayatına zaman ayıramadığını belirtmektedir.

10. Baş etme, stresi tolere etme şekli: İHT gün içinde sık sık ağlamaktadır. Hasta yakını, sosyal ve maddi destek kaynaklarının olmadığını belirtmektedir.

\section{Hemşirelik Bakım Planı ${ }^{2,11-16}$}

Gordonun fonksiyonel sağlık örüntüleri modeline göre toplanan veriler doğrultusunda hemşirelik tanıları konularak bakım planlanmıştır.

\section{Hemşirelik tanısı: Düşünce sürecinde değișim}

Neden: Serebral nöronların dejenerasyonu ve uyku paterninde bozulma.

\section{Hemşirelik Girişimleri:}

*Aile ile birlikte belleği güçlendirici girişimler (Psikomotor ve zihinsel aktiviteler) planlanarak hasta bireyin katılımı sağlanmalı,

*Takvim kullanarak gün, ay, yıl her gün hatırlatılmalı ve takvim üzerinde yazan yazılar okunmali,

*Saat üzerinde saatin kaç olduğu hatırlatılmalı, *Hastaya ismi ile hitap edilerek, açık-net anlaşılabilir iletişim sağlanmalı,

*Bulmaca çözme, gazete- kitap okuma, aile albümlerine bakılarak zihin canlı tutulması sağlanmali,

*Basit günlük aktiviteler (haşlanmış yumurta soyma, çorap eşleme, çöpü atma, çamaşır asma vb.) yapılması için plan yapılmalı, aktivitelerin yapımında zaman tanınmalı, yapilmas1 gerekenler gerektiğinde tekrar hatırlatılmalı,

*Giysi ve kıyafetlerin kolay giyilebilir olanları tercih edilmeli, kıyafetler takım halinde (iç çamaşırı-giyecekleri) hastaya sunulmalı,

* Akraba, eş-dost ziyaretlerinin planlanması, birlikte yürüyüş yapma gibi sosyal aktiviteler sürdürülmeli,

*Hastada var olan mizaç değişikliği, halüsinasyonlar ve hezeyanlar hasta yakını ile konuşularak belirlenmeli,

*Halüsinasyonları ve illüzyonları dikkate alarak; kendini güvende hissetmesi, düşme riskinin azaltılması açısından gece 1şıklandırması uygun yapılmalı ve etkin iletişim sürdürülmeli,

* Hekim tarafindan önerilen ilaçlar düzenli kullanilmalı.

Beklenen sonuç: Bilişsel işlevlerin en üst düzeyde sürdürülebilir olması.

\section{Hemşirelik tanısı: Huzursuzluk \\ Neden: Nörodejenerasyona sekonder gelişen frontal işlevlerde bozulma.}

\section{Hemşirelik Girişimleri:}

*Mümkünse bakım verilen ortam ve kişiler değiştirilmemeli,

*Stresten uzak, çevresel uyaranların (gürültü, parlak ışık vb.) sınırlı olduğu ortam sağlanmalı, *Hasta ile iletişimde kısa ve basit sözcüklerle, alçak ses tonuyla konuşulmalı,

*Göz teması kurularak tane tane konuşulmalı ve anlaşılmayı arttırmak için el, kol hareketler, mimikler etkili kullanılmalı,

*iletişimde aynı anda birden fazla soru sorulmamal1,

*Sık kullandığ1 özel eşya (takma diş, gözlük) kolay ulaşabileceği yerde bulundurulmalı,

*Ajitasyonu arttıracağı için hasta bir odaya ya da yatağa bağlanmamal,

*Kullanılan İlaçların etki ve yan etkileri yönünden hasta gözlenmeli.

Beklenen sonuç: Bireyin huzurlu, yeterli ve uygun iletişimi sürdürebiliyor olması.

3. Hemşirelik tanısı: Uyku paterninde bozulma

Neden: Huzursuzluk

\section{Hemşirelik Girişimleri:}

*Gün içinde uyanık kalması sağlanmalı, uyuklamalar önlenmeli,

*Sakin huzurlu bir ortam sağlanmalı, 
*Yatmadan önce uykuyu etkileyecek aktivitelerden (yemek yeme, egzersiz) sakınılmalı, *Çevresel uyaranlar azaltılmalı,

* Televizyon, telefon gibi ajitasyona neden olacak gürültü kaynaklarından uzak bir oda tercih edilmeli,

*Yatmadan önce kafeinli gıdaları tüketmesi önlenmeli,

* Uyandığında kendisini dinlenmiş hissedip, hissetmediği sorulmalı. Uyandığında sakin, sinirli, gergin, mutlu olup olamadığı değerlendirilmeli.

Beklenen sonuç: Yeterli uyku ve dinlenmenin sağlanmış olması

4. Hemşirelik tanısı: Öz bakım eksikliği Neden: Bilişsel süreçlerde bozulma.

\section{Hemşirelik Girişimleri:}

* Bireyin mümkün olduğunca bağımsızlığı korunmal1,

*Bakımlı ve temiz görünmesine yönelik teşvik edici iletişim kurulmalı,

* Kolay giyebileceği kıyafetler tercih edilmeli.

*Yerine getiremediği öz bakım aktivitelerinde (banyo yapma, tuvalet, diş firçalama, kıyafet giyme vb.) desteklenmeli,

*Cilt bütünlüğünün korunmasına yönelik uygulamalar planlanmalı.

Beklenen sonuç: Kendi bakımına en üst düzeyde aktif katılımı ve sürdürebiliyor olması.

5. Hemşirelik tanısı: Travma riski

Neden: Bilişsel yetersizliğe bağlı olarak çevredeki tehlikelerin farkına varamama.

\section{Hemşirelik Girişimleri:}

*Görme ve işitme duyularının kontrolü yapilmali,

*Evdeki mobilyalar ve aksesuarlar yaralanmayı önleyici şekilde seçilmeli,

*Ayak tabanı kaydırmaz, uygun ayakkabı seçilmeli,

* Mutfakta kesici aletler kaldırılmalı,

* Ocaklar belli süre açık kaldıktan sonra

kapanacak şekilde ayarlanmalı,

*Oda ve koridordaki halı ve kilimler

sabitlenmeli,

*Banyo yönünü belirten bantlar kullanılmal1, tuvalete giden yolların aydınlatılması ve güvenliği sağlanmalı,

* Emniyetli 1sı kontrolü sağlanarak su sıcaklıkları 37 derecede sabitlenmeli (yanıkları önlemek için).

*Banyoda kaymayan paspaslar kullanılmalı,
*Banyoda küveti doldurarak yıkanmak yerine oturarak duş yapılmalı

*Prizlerde koruma aparatı olmal1.

Beklenen sonuç: Kaza ve yaralanma yaşamadan güvenli bir ortamda yaşamını sürdürüyor olması.

6. Hemșirelik tanısı: Kaybolma riski

Neden: Bilișsel ișlevlerde bozulma.

\section{Hemşirelik Girişimleri:}

*Hastanın yanında tanıtıcı bir kimlik kartı, ulaşılacak adresin bulunduğu bir künye bulundurulmal1,

*Künye taşımak istemeyen bireylerin kıyafetine hastanın ad-soyadı, ulaşılacak kişinin telefonu ve adresi eklenmeli,

*Gözetimsiz dışarı çıkmasına izin verilmemeli,

* Kapı ve camlar için gereken önlemler alınmalı,

*Yakın çevre hastanın durumu hakkında bilgilendirilmeli,

* Kaybolma riskine karşılık hastanın son 6 aylık fotoğrafi bulundurulmali,

*Kaybolma durumunda başvurulacak kurumlar belirlenmeli.

Beklenen sonuç: Yakın ve uzak cevrede kaybolmamış olması

\section{Hemşirelik tanısı: Gereğinden çok} beslenme

Neden: Bilişsel süreçlerde bozulma.

\section{Hemşirelik Girişimleri:}

*Diyetisyen ile bir birlikte kalori hesaplamas1 yapılarak, yeterli ve dengeli beslenmesi sağlanmal,

*Beden ağırlığı korunmalı, kilo takibi yapılmalı *Yemek yeme saatleri hatırlatılmal1,

*Yemekte neler olduğu söylenmeli, gerekirse yemek adları hatırlatılmalı,

* Gereksiniminden fazla beslenmesini önlemeye yönelik olarak, yemek sonrası tekrar yemek isteğinde dikkati başka yöne çekilmeli,

*Konstipasyonu önlemek için diyette lifli gidalara yer verilmeli.

Beklenen sonuç: Yeterli ve dengeli besleniyor olmas1.

8. Hemşirelik tanısı: Aile içi baş etmede yetersizlik riski

Neden: Nöropsikiyatrik belirtiler ve uzun süreli bakım gereksinimi.

\section{Hemşirelik Girişimleri:}

*Hastalık hakkında bakım verene kısa bilgi verilmeli, 
*Duygu ve düşüncelerini paylaşmalarına firsat tanınmali,

*Bakım veren aile üyelerine öz-bakım uygulamalar1, aktivite planlama, hasta birey ile iletişim konularında bilgi verilmeli,

*Hasta bakımını kolaylaştırıcı araç ve gereçler, transfer teknikleri ve vücut mekanikleri ögretilmeli,

*Bakım veren aile üyelerine destek ve danışmanlık sağlanmalı,

* Aile üyelerinin destek gruplara katılımı, alternatif sağlık bakım kuruluşları hakkında bilgi verilmeli,

*Etkin baş etme yöntemleri hakkında bilgilendirilmeli,

*Bakım verenin sosyal aktivitelere katılımı ve kendine zaman ayırmasının önemi vurgulamalı.

Beklenen sonuç: Bakımı üstlenen kişilerin, evde bakımı uygun şekilde sürdürebiliyor, destek alıyor ve kendi sosyal yaşantılarını sürdürebiliyor olması.

\section{Tartışma}

AH; merkezi sinir sisteminin çeşitli kısımlarında nöron ve sinaps kayıpları ile ortaya çıkan kognitif fonksiyon bozuklukları, öz bakım yetersizlikleri, çeşitli nöropsikiyatrik ve davranışsal bozuklular ile karakterize bir hastalıktır $^{6,17}$. Yaşlanmanın normal bir süreci değildir $^{18}$. Unutkanlığın yaşl1lığa bağlı doğal belirtiler olarak düşünülmesi Alzheimer hastalığının erken tanısını engelleyebilmektedir. Yaş, düşük eğitim düzeyi ve düşük sosyoekonomik düzey risk faktörleri arasında yer almaktadır ${ }^{3}$. Hastalığın prevelansı, 65-85 yaşları arasında her beş senede bir iki katına çıkmaktadır ${ }^{10}$. Song ve ark. (2014) çalışmalarında yaş ortalaması 74.55 (min. 51.5, max: 89.3), Kwak ve ark. (2015) çalışmalarında $74.6 \pm 7.5$ yıl olarak belirtilmiştir ${ }^{19,20}$. İHT ilkokul mezunu, 75 yaşında, emekli ve sosyo-ekonomik düzeyi düşüktür.

Hastalar genellikle, Hafif Bilişsel Bozulma (HBB) evresinde küçük unutkanlık şikayetleri ile hastaneye gelmektedirler ${ }^{21}$. Wackerbarth ve Johnson'1n (2002) çalışmalarında unutkanlık ve davranış değişikliğinin fark edilen ilk belirti olduğu saptanmıştır' ${ }^{22}$. Akyar ve ark. (2009), çalışmalarında hastalığın ilk belirtisi olarak unutkanlığ 1 (\%58), davranış değişikliklerini $(\% 48)$, ve oryantasyon bozukluğu (\%48) olarak ifade etmişlerdir ${ }^{3}$. İHT 2 yıl önce sağlik kuruluşuna günlük yaşantısını etkileyen unutkanlık şikayetiyle başvurmuştur ve ilerleyen evrelerde davranış değişiklikleri görülmeye başlamıştır. Hasta yer ve zamana oryante değildir. Akyar ve ark. (2009) çalışmasında bakım verenlerin ifadesine göre hastaların var olan sorunları incelendiğinde \% 82 beslenme, \% 80 iletişim, \% 48 amaçsız gezinmeler, \%56 ile uyku sorunu yaşadıklarını saptamışlardır ${ }^{3}$. WolfKlein ve ark (1992) çalışmalarında hastaların \%92 beslenme sorunu, Cole ve Richards (2005) \%43 sıklıkta uyku sorunu yaşadıklarını saptamışlardır ${ }^{23,24}$. Cummings'e göre Alzheimer hastalarında halüsinasyonlar \%10-73 gibi oranlarda görülebilmektedir. ${ }^{25}$ Akyar ve ark.(2009) çalışmalarında hastaların \%62halüsinasyon sorunu yaşadığı saptanmıştır ${ }^{3}$. IHHT evde amaçsızca dolaşmakta, yemek yediğini unutup tekrar yemek istemekte, yapılacak aktivitelere direnmekte ve hasta yakını tarafından geçinilmesi zor biri olarak biri olarak tanımlanmaktadır. Hasta yakınları beslenme, halüsinasyon, uyku problemi gibi sorunlarla karşılaştıklarında alacağı önlemler ve hastaya yaklaşım konusunda bilgilendirilmelidir. Akyar ve ark. (2009) çalışmasında bakım verenlerin \%44'ünün bakım ile ilgili, \%18'inin uygulama ile ilgili bilgiye gereksinim duyduğu saptanmıştır ${ }^{3}$. Hastalı̆̆ın tanısında; hasta öyküsü, KMDT, CDR kullanılmıştır. 1975 yılında Folstein ve ark. tarafindan geliştirilen KMDT hafiza, dikkat, bellek işlevleri, lisan, motor fonksiyon, algilama ve vizospasiyel yetenekleri test etmektedir. On bir sorudan oluşmakta ve 30 puan üzerinden değerlendirilmektedir. Yirmi dört-otuz puan aras1 normal, 18-23 puan arası hafif demans, 17 puan ve alt1 ciddi demansla uyumludur., 926,27 İHT uygulanan KMDT'inden 11 puan almıştır, ciddi demans ile uyumludur. Hughes ve ark. 1982 yılında geliştirilen CDR, demans derecesinin klinik açıdan değerlendirilmesini sağlar. Bellek, oryantasyon, yargılama ve problem çözme, ev dışında işlevsellik, ev yaşamı ve hobiler, kişisel bakım olmak üzere başlıca 6 alan değerlendirilmektedir. ${ }^{28}$ Evre 0: Normal yaşlılık, Evre 0,5:Hafif Kognitif Bozukluk, Evre 1:Erken Evre Demans, Evre 2:Orta Evre Demans, Evre 3:İleri Evre Demans olarak sinıflandırılmaktadır. ${ }^{29}$ IHT uygulanan klinik demans evreleme ölçeğine göre ileri evre demans olarak tanımlanmıştır. Hastalığın erken evrede tedavi sürecinin başlatılması hastanın ve bakım verenin sağllğının sürdürülmesi açısından önem taş1maktadir ${ }^{3,30}$.

Alzheimer hastalarının yaşadıkları sorunlar ve bakım gereksinimleri bakım veren- 
leri etkilemektedir. Bakım verenlerin hasta için ayırdıkları zamanın çokluğu kendi günlük yaşamlarının etkilenmesine neden olmaktadır ${ }^{3}$. İHT nin oğluna; bakım gereksinimi olan bireye veya yaşlıya bakım verenlerin yaşadığ 1 stresi değerlendirmek amaciyla kullanılan 1980 y1lında Zarit ve ark. tarafından geliştirilen '’Bakım verme yükü ölçeği '’uygulanmıştır. Ölçek bakım vermenin bireyin yaşamı üzerine olan etkisini belirleyen 22 ifadeden oluşmaktadır. Ölçekten en az 0 , en fazla 88 puan alınabilmektedir. Ölçek puanının yüksek olması, yaşanılan sıkıntının yüksek olduğunu göstermektedir. ${ }^{31}$ Hasta yakınının ölçekten aldığı puan 85 tir. Hasta yakını İHT'nin ihtiyac1 olduğundan fazla yardım istediğini ve kendi günlük yaşamını yaşayamadığını belirtmektedir. Akyar ve ark. (2009) çalışmalarında bakım verenlerin \%90'1 bakım verme nedeniyle günlük yaşamlarının etkilendiğini ifade etmişlerdir. ${ }^{3}$

Hasta yakınları kendileri için dinlenme periyotları ayırmalı ve aktivitelere katılımı için desteklenmelidir. Hasta bakımında yararlanabilecekleri kaynaklar ve ulusal düzey-deki dernekler hakkında bilgilendirilmeleri bakım verme yükünü azaltacaktır.

\section{Sonuç}

Hasta ve hasta yakını hemşirelik bakım planı içinde ele alınarak hemşirelik girişimleri uygulandı. Hemşirelik tanılarına göre; hasta yakınına bakımda uygulaması gerekenler ve hasta bakımında yararlanabileceği kaynaklar hakkında bilgi verildi. Hasta yakını, düzenli sağlık kontrolünün önemi ve ilaçların doğru kullanımı hakkında bilgilendirildi. Hasta yakınına, kendisine vakit ayırması ve yaşamın içinde olmasının babasına vereceği bakımın kalitesini arttıracağı belirtildi.

Sonuç olarak; Alzheimer hastalığında erken tanı ve tedavinin başlanması hasta ve bakım veren açısından önemlidir. Uzun süreli bakım gerektiren AH'lığında disiplinlerarası yaklaşım ve ekip çalışması ile hasta ve ailesi bir bütün olarak ele alınarak bakım planlanmalıdır. Hasta yakınları / bakım verenler hastalık hakkında, ulusal düzeydeki dernekler ve hasta bakımında yararlanabileceği kaynaklar hakkında bilgilendirilmelidir.

\section{Kaynakça}

1. İşeri PK, Efendi H. [Efficacy and safety of donepezil and rivastıgmine in alzheimer's disease]. Turkish Journal of Geriatrics 2003; 6(4):119-123.
2. Karadakovan A. Yaşlı sağlığı ve bakım. 1 . Baskı. Ankara: Akademisyen Tip Kitap evi; 2014. s.328-334.

3. Akyar İ, Akdemir N. [Strains of caregivers of alzheimer patients]. Hacettepe University Faculty of Health Sciences Nursing Journal 2009; 3:32-49.

4. Alzheimer's Association. 2016 Alzheimer's Disease Facts and Figures. Alzheimer's \& Dementia 2016;12(4):910.

5. Selekler K. Alois alzheimer ve alzheimer hastalığ 1 [Alois alzheimer and alzheimer's disease]. Türk Geriatri Dergisi [Turkish Journal of Geriatrics] 2010; 13(3):9-14.

6. Özkay ÜD, Öztürk Y, Can ÖD. Yaşlanan dünyanın hastalığı: alzheimer hastalığ1 [Aging World disease: Alzheimer's disease]. SDÜ Tıp Fakültesi Dergisi 2011; 18(1):35-42.

7. Öztürk E. Dünya alzheimer farkındalık günü 2015, http://www.tkhk.gov.tr/, Erişim Tarihi: 30.05.2016.

8. Gacar M. Adı eylül. 1. Baskı. İstanbul: Nobel Tip Kitapevi; 2009.s.208-209.

9. Yavuz BB. Geriatrik değerlendirme ve testler [Geriatric evaluation and tests]. İç Hastalıklar1 Dergisi 2007; 14(1): 5-17.

10. Topçuoğlu ES, Kaynak S. Alzheimer hastalığ1 [Alzheimer disease]. Geriatri [Turkish Journal of Geriatrics] 1998; 1(2):63-67.

11. Küçükgüçlü Ö. Alzheimer hastalığı ve hemşirelik bakımı [Alzheimer's disease and nursing care]. Demans Dergisi 2003; 3(3): 86-92.

12. İlçe AÖ, İlçe AC, Diramalı A. Yaşlılarda ev kazalarının önlenmesi ve ev kazalarının önlenmesine yönelik iç mekan çözümlemeleri [Preventing home accidents in the elderly and in order to prevent of home accidents of different alternatives in indoor furnitures] http://www.sdergi.hacettepe.edu.tr/makal eler/aiciad.pdf, Erişim Tarihi: 30.05.2016.

13. Akdemir N, Birol L. İç hastalıkları ve hemşirelik bakımı. 2. Baskı. Ankara: Sistem ofset; 2004. s.839-843.

14. Mauk KL. Çevi: Özdemir L, Sütçü Çiçek H. Rehabilitasyon Hemşireliği. 1. bask1. Ankara: Nobel Akademik Yayıncılık; 2014.s.434. 
15. Durna Z. Kronik Hastalıklar ve bakım. 1. Baskı. İstanbul: Nobel Tip Kitapevleri; 2012.s.534-535.

16. Enç N. İç Hastalıkları Hemşireliği. 1. Bask1. İstanbul: 50.Y11 Yayınlar1; 2014.s.325-330.

17. Rolland Y, Pillard F, Klapouszczak A, Reynish E, Thomas D, Andrieu S, Riviere $D$, Vellas B. Exercise program for nursing home residents with alzeheimers disease: a 1-year randomized, controlled trial. The American Geriatrics Society 2007;55(2): 158-165.

18. Goldman WP, Morris JC. Evidence that age-associated memory impairment is not a normal variant of aging. Alzheimer Dis Assoc Disord 2001; 15(2): 72-79.

19. Song Y, Zang D, Wang Z, Guo J, Gong Z, Yao Y. Grand total eeg analyses: a promising method predict the severity of cognitive impairment in alzheimer'sdisease. Journal of Neurological Sciences 2014; 3(1): 40-46.

20. Kwak YT, Song SH, Yang YS. The relationship between geriatric depression scale structure and cognitive-behavioral aspects in patients with alzheimer's disease. Dement Neurocognitive Disord 2015; 14(1):24-30.

21. Öziç MU, Özbay $Y$, Ekmekçi AH. [Extraction of features of Alzheimer Disease on Brain MR Images]. Tip Teknolojileri Ulusal Kongresi 2014; 3841.

22. Wackerbarth S, Johnson M. The carrot and the stick: Benefits and barriers in getting a diagnosis. Alzheimer's Disease and Associated Disorders 2002;16(4) :213-220.

23. Wolf-Klein GP, Silverstone FA, Levy AP. Nutrional patterns and weight changes in Alzheimer patients. International Psychogeriatrics 1992; 4(1):103-111.

24. Cole C, Richards K. Sleep and cognition in people with Alzheimer's disease. Issues in Mental Health Nursing 2005; 26(7): 687-698.

25. Cummings JL.Çev: Kara-Sevin K. [Recognition and treatment of behavioral disorders in Alzheimer's disease and other dementias]. Turkish Journal of Neurology 1996; 2(3-4): 113-120.

26. Kalem ŞA, Öktem Ö, Emre M. [Determination of the descpriptive statisitcs for short blessed orientation-memoryconcentration test (BOMC) and standardizad mini mental state examination test (SMME) in an normal Adult Turkish sample]. Archives of Neuropsychiatry 2002; 39(2-3-4): 95-102.

27. Bravo G,Hebert R. Age-and educationspecific reference values for the mini mental and modified mini-mental state examinations derived from a nondemented elderly population. International Journal of Geriatric Psyhiatry 1997; (12): 1008-1018.

28. Akdemir A, Cangöz B, Örsel S, Selekler K. Hafif A comparison of 1mplicit memory performance in mild cognitive 1mpairment and alzheimer type dementia patients]. Turkish Journal of Psychiatry 2007; 18(2): 118-128.

29. Babacan Yıldız G, Ur Özçelik E, Kolukısa M, Işık TA, Kocaman G, Çelebi A. [Validity and reliability studies of modified mini mental state examination (mmse-e) for turkish 1lliterate patients with diagnosis of alzheimer disease] Turkish Journal of Psychiatry] 2015; (26): 1-8.

30. Atlı T. Yaşlıda unutkanlığa yaklaşım. [Approach to amnesia of elderly]. Klinik Gelişim 2012; (25): 24-28.

31. İnci $\mathrm{FH}$, Erdem $\mathrm{M}$, [Validity and reliability of the burden interview and its adaptation to Turkish]. Atatürk Üniversitesi Hemşirelik Yüksekokulu Dergisi 2008; 11( 4): 85-95. 